\title{
The effects of financial crisis on birth rates in Halabja province from 2014 to 2018
}

\section{Ayub Hasan Abudlqadir *, Bilal Esmail Hama **, Shahen Mohammaed Faraj $* * *$}

* General Directorate of Health of Halabja, Halabja, Iraq - Kurdistan

** Ministry of Education, Iraq - Kurdistan

*** Department of physic, university of Halabja, Halabja, Iraq - Kurdistan

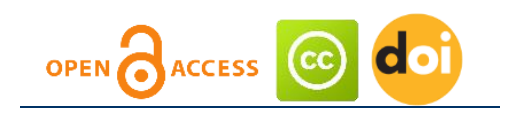

Article history:

Received: March 30, 2020

1st Revision: August 10,

2020

Accepted: October 25,

2020

JEL classification:
H12
O18
R23
R58

\begin{abstract}
This study indicates the effects of financial crisis on birth rates in the Halabja province. Specifically, the results are shown that financial crisis that occurred from 2014 to 2018 make a steady decline in the birth rates in Halabja province. The data used in this paper are (the number of population, the number of birth and the number of death) through this period. The Data Description, five statistic formulas and SPSS version 22 are used to analyze these data. The results show that there is a strong relationship between the financial crisis and birth rates in Halabja province during financial crises period.
\end{abstract}

Keywords: financial crisis, birth rate, Kurdistan Regional Government.

\section{DOI:}

\section{Introduction}

A Recent financial crisis has occurred since 2014, in the Kurdistan Regional (KR). These crises have a series of effects on birth rates in Halabja province ${ }^{1}$. They mainly resulted from the political and economic problems between the Iraqi Central Government (ICG) and the Kurdistan Regional Government (KRG); in addition, the cost of fight against the ISIS. Since 2014 till 2018 the ICG stops sending the KRG's budget that is the main source of its budget which is 14,406,735,000,000 IQD billion out of its total 15,257.849,000,000 IQD billion (KRG, 2013). Hence, the KRG could not pay the employees' salary, investment and construction projects failed to be continued and unemployment had been outspread, consequently the families' income rate decreases, as a result, the economic crisis has affected badly on birth rates because it is the logical result of poverty.

\footnotetext{
${ }^{1}$ Halabja province: in 2014 Halabja has become a province by (KRG), it is located at east of slumanyah province and nearly 90
} $\mathrm{KM}$ far from slumanyah, in north of Iraq. Geographically this province is isolated, also it is not economical city. 
It is expressed that financial crises have been pervasive phenomena throughout history (Franklin, Ana, \& Elena, 2010). Financial crises do arise in many types, however, they have common elements. A financial crisis is often associated with one or more of the following phenomena: substantial changes in credit volume and asset prices; severe disruptions in financial intermediation and the supply of external financing to various actors in the economy; large scale balance sheet problems (of firms, households, financial intermediaries and sovereigns); and large-scale government support (in the form of liquidity support and recapitalization). As such, they are typically multidimensional events and can be hard to characterize using a single indicator (Stijn \& Ayhan Kose, 2013). Financial crises are disconcerting events. At first, they seem impenetrable, even as their damage undeniably grows and becomes increasingly widespread (Zandi, 2008).

Besides, the birth rates (also called the crude birth rates) indicates the number of live births per 1,000 populations in a given year (Haupt \& Kane, 2000). Crude Birth Rate is the number of resident live births for a specified geographic area (nation, state, county, etc.) during a specified period (usually a calendar year) divided by the total population (usually mid-year) for that area and multiplied by 1,000 .

When the financial crisis took place, it changed the situation from growth to decline. Decreasing the marriage rates among youth in the KR is one of the main effects of the financial. Particularly in Halabja because this city is not an economical place. Another effect is decreased birth rates because of the cost of childbearing so high. The family decided to postpone childbearing.

\section{Literature review}

There are several empirical studies on the effects of financial crises on the birth rates. Nevertheless, some conflicting results are shown the effects of financial crises on the birth rates. For instance, (Doo, et al., 2014) examined the relationship between economic crises and the birth rates, Comparison between South Korea and Italy for the period (1997-2007). It is concluded that the Economic crisis has a bad impact on birth rates, and it can decline the birth rates especially at the time of crises. This result is in line with the results of (Davalos \& Morales, 2017) examined the impacts of economic crises on birth rates. They had analyzed the data in Latin America-Colombia from 1998 to 2013. It is found that is the economic crisis has an impact on birth rates in poor area and decline by 0.002 children per women, while in the well of states birth rates increase by 0.007 children per women.

(Sobotka, Skirbekk, \& Philipov, 2010) analyzed the impact of the Economic crisis on birth rates in the developed world, they used the data from 1980 to 2008, and their result illustrated that the Economic crisis declines the birth rates. Similar results investigated by (Dommermuth \& Lappegard, 2016) that the global crisis of 2007-2008 has decreased the birth rates in Norway, they used the date from 1990 to 2015, and a new postponement of the first-births after 2009 is observed.

Furthermore, (Kotzamanis \& Kostaki, 2016) analyzed the effects of economic recession which occurred in developed countries on birth rates. They found that there is a negative relationship between economic recession and birth rates. Directly the economic recession decreased birth rates in Greece. They used the data from 1951 to 2013. Moreover, (Billingsley, 2009) tries to estimates the impact of the economic crisis on Russia's birth rates decline. It is expressed that the economic crisis had a bad effect on the rate of birth. He used the data between the years 1991- 2007. Other research has done by (Graham, Sabater, \& Francesca, 2016), they try to explain how the economic crisis can decline the birth rates in Italy and Spain. They used the data between 2004-2013, especially during the economic crisis of 2008. Their research proved that the economic crisis had negative effects on the birth rates in two countries.

\section{Data collection and methodology}

\subsection{Data collection}

This paper uses the number of birth and death data for 5 years that collected from the General Directorate of Health of Halabja (GDHH), and the net number of population collected from the Halabja Statics Office (HSO) and the Halabja Governorate (HG). The analyzed period covers 5 years, from 2014 whereas the financial crisis has been arisen in the KRG to 2018. 


\subsection{Methodology}

The analyses are based on administrative register data for the net population in Halabja province in the KRG for the period 2014-2018. Five statistic formulas are used to find out the effect of financial crisis and decline of birth rates in difference years, such a Crude Birth Rate, Crude Death rate, and Natural Increase Rate, population increasing percentage and the growth rates of population. In addition; to using SPSS version 22 to find the regression and the relationship between financial crisis and birth rates, also to find correlation the neutral relationship between financial crisis and birth rates. * 1000 .

1) - Crude Birth Rates= Number of birth in a specific year/Mid-year population for same year

2)- Crude Death Rates= Number of death in a specific year/Mid-year population for same year * 1000.

3)- Natural Increase Rate of population= Crude Birth Rate-Crude Death Rate/10.

4)-population increasing percentage $=\mathrm{P}_{2}-\mathrm{P}_{1} / \mathrm{P}_{1} * 100$.

Where:

$\mathrm{P}_{1}=$ population in the first census.

$\mathrm{P}_{2}=$ population in the last census.

$5)$ - The growth rates of population or $\mathrm{R}=\mathrm{LN}(\mathrm{P} 2 / \mathrm{P} 1) / \mathrm{T} * 100$.

$\mathrm{R}=$ growth rates population.

LN= Natural Logarithm.

$\mathrm{P} 1=\mathrm{P}_{1}=$ population in the first census.

$\mathrm{P} 2=$ population in the last census.

$\mathrm{T}=$ The difference between censuses.

\subsection{Data description}

\begin{tabular}{|c|c|c|c|c|}
\hline Years & $\begin{array}{c}\text { No of Net } \\
\text { Population/Thousand }\end{array}$ & $\begin{array}{c}\text { The Number of } \\
\text { Mid-Year } \\
\text { Population } \\
\end{array}$ & No. Birth & No. Death \\
\hline 2014 & 105,245 & 103,497 & 3,496 & 350 \\
\hline 2015 & 108,161 & 106,543 & 3,236 & 320 \\
\hline 2016 & 110,803 & 109,309 & 2,989 & 347 \\
\hline 2017 & 112,086 & 111,264 & 1,644 & 361 \\
\hline 2018 & 113,363 & 112,566 & 1,594 & 317 \\
\hline
\end{tabular}

Source: Halabja Stastisics Office, 2/11/2019 and the General Directorate of Health of Halabja. 10/11/2019 and the Net Number of Population in 2019 (114,632)

The Table 1 shows the net number of population, the number of mid-year population, the number of birth and the number of death in Halabja province during the crises years. it is clear that there is an increase in the population which refers to the birth, but It is observed that the number of birth declined steadily during crises period that affects population growth. In 2014 which is the year that the crises arisen, the birth number is 3,496, but the number fallen to 1,594 in 2018 , which shows big declining in the numbers of new born.

On the other hand, the table indicates that during financial crises population number is increased, but this increasing is regressed instead of growing. As the data shows, in 2014 the population net is 105,245 , in 2015 it is increased to 108,161 , means that in one year 3,496 add to the population, but in the last two years 2017 and 2018 just 3,238 add to the population net. 


\begin{tabular}{|c|c|c|c|c|c|c|c|c|}
\hline $\begin{array}{c}\text { Year } \\
\text { s }\end{array}$ & $\begin{array}{c}\text { Crude Birth Rates } \\
\text { / Per } \\
\text { Thousand/percen } \\
\text { tage }\end{array}$ & $\begin{array}{c}\text { Crude Death } \\
\text { rates/ Per } \\
\text { Thousand/percen } \\
\text { tage }\end{array}$ & $\begin{array}{c}\text { Natural } \\
\text { Increase } \\
\text { Rates/percent } \\
\text { age }\end{array}$ & $\begin{array}{l}\text { Populatio } \\
\mathrm{n} \\
\text { increasin } \\
\text { g } \\
\text { percenta } \\
\text { ge }\end{array}$ & $\begin{array}{l}\text { The growth rates } \\
\text { population/percen } \\
\text { tage }\end{array}$ & $\begin{array}{l}\text { Birth } \\
\text { decline } \\
\text { d rate }\end{array}$ & $\begin{array}{c}\mathrm{R}^{2}(\mathrm{R} \\
\text { square } \\
\text { ) }\end{array}$ & $\begin{array}{c}\text { Pearson } \\
\text { Correlati } \\
\text { on } \\
\text { Coefficien } \\
\text { t }\end{array}$ \\
\hline 2014 & 33.21 & 3.32 & 32.88 & 3 & 2.73 & 0 & .887 & -.942 \\
\hline 2015 & 29.91 & 2.95 & 29.62 & 2.44 & 2.41 & -7.43 & & \\
\hline 2016 & 26.97 & 3.13 & 26.66 & 1.15 & 1.15 & -14.50 & & \\
\hline 2017 & 14.66 & 3.22 & 14.34 & 1.13 & 1.13 & -52.97 & & \\
\hline 2018 & 14.06 & 2.79 & 13.78 & 1.11 & 1.11 & -55.00 & & \\
\hline
\end{tabular}

The above table second column indicates that the crude birth rates through the financial crisis period sharply decreased. In 2014 it is 33.21 percent, in 2015 it is 29.91 percent, in 2016 it is 26.97 percent, in 2017 it is 14.66 percent and it is decreased to 14.06 percent in 2018 . Third column indicates that the crude death rates are normal.

Fourth column indicates that the natural increase rates are decreased because of financial crisis, in 2014 it is 32.88 percent, in 2015 it is 29.62 percent, in 2016 it is 26.66 percent, in 2017 it is 14.34 percent and in 2018 it is 13.78 , it shows that the natural increase rates is slowly increased.

Fifth column indicates that the Population increasing percentage in 2014 is 3 percent, in 2015 is 2.44 percent, in 2016 is 1.15 percent, in 2017 is 1.13 percent and in 2018 it is 1.11 percent; it shows that the population increasing percentage sharply decreased.

Sixth column shows that the growth rates population is decreased; in 2014 the growth rate of population is 2.73 percent, in 2015 the growth rate of population is 2.41 percent, in 2016 the growth rate of population is 1.15 percent, in 2017 the growth rate of population is 1.13 percent and in 2018 it was 1.11 percent, it shows that these rates were decreased sharply.

Moreover, seventh column shows the comparison between years 2015, 2016, 2017 and 2018 to 2014 , in 2015 the declined ratio is 7.43 percent compare to 2014 , in 2016 it is 14.50 percent decreased, also in 2017 decreased to 52.97 percent, while in 2018 the ratio decreased to 54.40 percent, which explains that the birth rates in the Halabja province has been affected strongly by financial crises.

Eighth column shows The $\mathrm{R}^{2}$ it is .887 which is shows that there is a great relationship between financial crises in Halabja province and birth rates (Pallant, 2013). The $\mathrm{R}^{2}$ indicates that the model is well fitted.

A correlation coefficient is used in statistics to describe a pattern or relationship between two variables. A negative correlation describes the extent to which two variables move in opposite directions also if Pearson Correlation Coefficient equal or nearby $(-1)$ it means a perfect negative (downward sloping) linear relationship (Silver, 2019). Then the ninth column shows the Pearson Correlation Coefficient it is (-.942), that means there is a negative correlation between financial crisis and birth rates in Halabja Province.

Graph 1: Birth rate

NO.BIRTH

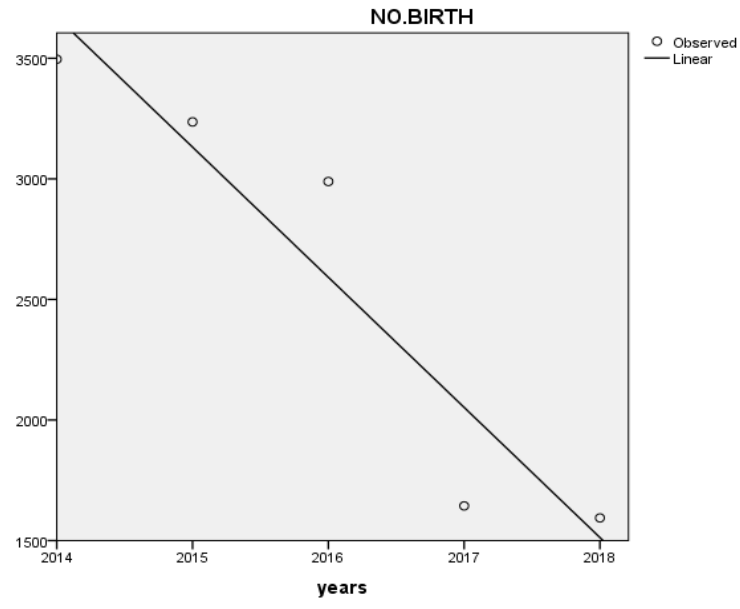


Graph 1 shows that the birth rates in Halabja province during financial crises period declined sharply to its lower point at 2018.

\section{Conclusion}

This study investigates the effects of the financial crisis on birth rates in Halabja province in the KR -north of Iraq. Based on the nature of the data used, the financial crisis has effects on the birth rate. The result explores that the financial crisis badly has a strong impact on birth rates. Moreover, the impact would appear to be lagged and relatively modest.

Also, the financial crisis, which is picked up, is often first rather than the final step. Through the time of course because of the financial crisis become more effective, and it can decrease the birth rates. During this period. It was obvious that the salary has not paid salary for 50 days, the economic situation became worse, and the parents thought they did not have money to bring up a child for that they did not allow themselves to give birth a new child. The cost of grow up children needs a lot expenditure. Gradually the family has decided to stop form bearing child, it is the main reason to decrease birth rates.

\section{Citation information}

Nguembi, P., Zhang, Y., Abdalla, H. S. (2020). The effects of financial crisis on birth rates in Halabja province from 2014 to 2018. Economics, Management and Sustainability, 5(2), 132-137. doi:10.14254/jems.2020.5-2.10.

\section{References}

Billingsley, S. (2009). Fertility and Economic Crisis: Inflation, Wage Devaluation and Job Instability in Russia. Demography Unit, Dept. of Sociology. Stockholm University. Retrieved from https://www.su.se/polopoly_fs/1.18700.1320939633!/WP_2009_9.pdf

Davalos, E., \& Morales, L. F. (2017). The Economic crisis promotes fertility decline in poor areas: evidence from Colombia. The journal of Demographic Research, 37(27), 1-24. Retrieved from : https://www.demographic-research.org/volumes/vol37/27/37-27.pdf

Dommermuth, L., \& Lappegard, T. (2016). Fertility trends after the financial crisis in Norway. The journal of Research department, statistic Norway, 1-13. Retrieved from https://epc2016.princeton.edu/papers/160328

Doo, K., Rose, S., Gabrielli, A. D., Giuseppe, Paterno, \& Anna. (2014). Effects of the economic crises on fertility: A comparison between south Korea and Italy. The journal of sieds, LXIX(n), 1-15. Retrieved from http://www.sieds.it/listing/RePEc/journl/2015LXIX_2_RIEDS_223234_Kim_Gabrielli_DeRos e_et_al.pdf

Franklin, A., Ana, B., \& Elena, C. (2010). Financial Crises: Theory and Evidence. Journal of SSRN Electronic Journal, 1(1). Retrieved from https://papers.ssrn.com/sol3/papers.cfm?abstract_id=1599424

Graham, E., Sabater, A., \& Francesca, F. (2016). Fertility Change in the Context of Economic Recession in Italy and Spain. Centre for population change, 36, 1-4. Retrieved from http://www.cpc.ac.uk/docs/BP36_Fertility_Change_in_the_Context_of_Economic_Recession. pdf

Haupt, A., \& Kane, T. T. (2000). Population Handook (4 ed.). Washington, DC: Population Reference Bureau.

Kotzamanis, B., \& Kostaki, A. (2016). The Implications of the Recent Economic Crisis on Fertility in Greece. European Journal of Economics and Business Studies, 1, 1-18. Retrieved from http://journals.euser.org/files/articles/ejes_sep_dec_15/Byron.pdf 
KRG, B. (2013). KRG Budget Law, Kurdish Version: Retrieved from kurdistan parliament: https://www.kurdistan-parliament.org/files/articles/040313095603.pdf

Pallant, J. (2013). SPSS Survival Manual; A step by step guide to data analysis using IBM SPSS (5 ed.). MC-Graw Hill.

Silver, C. (2019). What Does a Negative Correlation Coefficient Mean? Retrieved from https://www.investopedia.com/ask/answers/041015/what-does-negative-correlationcoefficient-mean.asp.

Sobotka, T., Skirbekk, V., \& Philipov, D. (2010). Economic recession and fertility in the development word. Journal of Vienna Institute of Demography, 37, 1-37. Retrieved from https://www.pewresearch.org/wp-content/uploads/sites/3/2010/10/economic-recessionand-fertillity-2009.pdf

Stijn, C., \& Ayhan Kose, M. (2013). Financial Crises: Explanations, Types, and Implications. The journal of SSRN Electronic Journal, 13(28), 4 - 5. Retrieved from https://papers.ssrn.com/sol3/papers.cfm?abstract_id=2212005

Zandi, M. (2008). Financial shock. United States of America. Tim Moore.

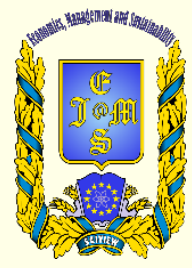

() 2016-2020, Economics, Management and Sustainability. All rights reserved.

This open access article is distributed under a Creative Commons Attribution (CC-BY) 4.0 license.

You are free to:

Share - copy and redistribute the material in any medium or format Adapt - remix, transform, and build upon the material for any purpose, even commercially.

The licensor cannot revoke these freedoms as long as you follow the license terms.

Under the following terms:

Attribution - You must give appropriate credit, provide a link to the license, and indicate if changes were made.

You may do so in any reasonable manner, but not in any way that suggests the licensor endorses you or your use.

No additional restrictions

You may not apply legal terms or technological measures that legally restrict others from doing anything the license permits.

Economics, Management and Sustainability (ISSN: 2520-6303) is published by Scientific Publishing House "CSR", Poland, EU and Scientific Publishing House "SciView", Poland

Publishing with JEMS ensures:

- Immediate, universal access to your article on publication

- High visibility and discoverability via the JEMS website

- Rapid publication

- Guaranteed legacy preservation of your article

- Discounts and waivers for authors in developing regions

Submit your manuscript to a JEMS at http://jems.sciview.net or submit.jems@sciview.net 